\title{
OPEM
}

www.opem.org

Oriental Pharmacy and Experimental Medicine 2010 10(2), 66-78

DOI 10.3742/OPEM.2010.10.2.066

\section{Toxicity studies on Trigonella foenum-graecum L. seeds used in spices and as a traditional remedy for diabetes}

\author{
RM Al-Ashban, RR Abou-Shaaban and AH Shah*
}

Central Laboratory for Drug Analysis, Ministry of Health and Saudi Food and Drug Authority Joint Venture, King Saud Medical Complex, P.O. Box 59082, Riyadh-11525, Saudi Arabia

Received for publication March 04, 2009; accepted April 06, 2010

\begin{abstract}
SUMMARY
Acute (24 h) and chronic (90 days) oral toxicity studies on the ethanol extract of Trigonella foenumgraecum Leguminosae (L.) seeds were carried out. Acute dosages were 0.5, 1.0 and $3 \mathrm{~g} / \mathrm{kg}$ while chronic dosage was $100 \mathrm{mg} / \mathrm{kg}$ per day of the extract. All morphological, biochemical, haematological and spermatogenic changes, in addition to mortality, body weight changes and any change in vital organs were recorded. Histopathological investigations were done on vital organs. Growth arrest in the treated animals was observed. The treated mice gained no significant weight during chronic treatment while there was a significant gain in body weight of the control group mice. Biochemical studies revealed a significant decrease in blood sugar levels of fenugreek treatment groups while haematological parameters remained comparable to the control. In the treatment, male group there was a significant decrease in weight of testes as compared to the control. There was a marginal weight gain in kidney weight of mice after chronic treatment as compared to the control. Fenugreek chronic treatment caused a highly significant spermatotoxic effects in male mice.
\end{abstract}

Key words: Fenugreek; Acute toxicity; Chronic toxicity studies; Slowness of growth; Blood glucose lowering potential; Spermatotoxic effect

\section{INTRODUCTION}

Trigonella foenum-graecum Leguminosae, (L.) commonly called 'fenugreek', is an annual herb, used in traditional medicine of different countries worldwide (Chopra et al., 1956; Gruenwald et al., 2000; Barnes et al., 2002; Malviya et al., 2010). Fenugreek seeds have an aromatic odor and characteristic bitter taste. Fenugreek is used for fragrance in spices and is known to possess various medicinal

\footnotetext{
*Correspondence: AH Shah, Central Laboratory for Drug Analysis, Ministry of Health and Saudi Food and Drug Authority Joint Venture, King Saud Medical Complex, P.O. Box 59082, Riyadh-11525, Saudi Arabia. Tel: +96614351900/1637; Fax: +96614353564; E-mail: ahshah@hotmail.com
}

properties (Hussein, 1985; Dweck, 1997; Beutler and DerMarderosian 2002; Shabbeer et al., 2009). Its seeds are claimed to have antidiabetic, mucilaginous, demulcent, laxative, nutritive, expectorant and orexigenic properties (Karawya et al., 1980; Duke, 2001; Barnes et al., 2002). The seeds have been documented as a traditional herbal treatment for diabetes in different countries (Khosla et al., 1995; Abdel-Barry et al., 1997; Hunt et al., 2000; Haddad et al., 2001).

Fenugreek seeds were also used traditionally in the treatment of dyspepsia, gastritis and convalescence, and topically for furuncolosis, myalgia, lymphadenitis, gout, wounds, inflammations and leg ulcers (Duke, 2001; Beutler and Marderosian 2002; Malviya et 
al., 2010). The crude infusion of the fenugreek seeds is used as tonic, carminative, antispasmodic (Duke, 2001), antidiabetic (Shani et al., 1974; Puri et al., 2002; Mondal et al., 2004), antioxidant (Thirunavukkarasu et al., 2003; Dixit et al., 2005), cytoprotective (Pandian et al., 2002), hepato-protective (Kaviarasan et al., 2007) anti-inflammatory (Vyas et al., 2008; Malviya et al., 2010), antimalarial control (Khater and Shalaby, 2008; Palaniswamy et al., 2008); antifungal (Haouala et al., 2008), antineoplastic (Sur et al., 2001; Amin et al., 2005), anti thyroid hormone (Kar and Tahiliani, 2003), immunostimulant (Bin-Hafeez et al., 2003), hypocholesterolaemic (Valette et al., 1984; Narender et al., 2006), diuretic and as a remedy against kidney stones (Ahsan et al., 1989; Rohini et al., 2009). Several such claims were confirmed experimentally. Various pharmacologically active compounds such as alkaloids (Shani et al., 1974; Duke, 2001; Zhao et al., 2003; Satheeshkumar et al., 2010); flavonoids (Adamska and Lutomski, 1971; Shang et al., 1998); tannin like phenolic compounds (Duke, 2001); polyphenols (Kaviarasan et al., 2008); steroids (Taylor et al., 1997); saponins (Dawidar et al., 1973; Pasich et al., 1983; Gupta et al., 1986; Yoshikawa et al., 1997; Sauvaire et al., 1998; Murakami et al., 2000; Raju et al., 2004; Yang et al., 2005); dioscin; free amino acids (Duke, 2001); an unusual amino acid 4-hydroxyisoleucine (Haefelé et al., 1997; Sauvaire et al., 1998; Haeri et al., 2009); coumarin derivatives (Khurana et al., 1982); lipids (Beutler and Der Marderosian, 2002); phospholipids (Xu et al., 1992); mucilaginous fibers (Srichamroen et al., 2009); vitamins; and minerals have been isolated from fenugreek seeds (Farnsworthand Marles, 1995; Duke, 2001). Some of the steroidal saponins isolated from fenugreek seeds, were found to stimulate growth-hormone release in rat pituitary cells (Shim et al., 2008), while higher phenol and polyphenols contents of fenugreek controlled oxidative damage (Kaviarasan et al., 2007; Dixit et al., 2008; Kaviarasan et al., 2008).

As regards the toxicity of fenugreek treatment is concerned, in some patients rhinorrhea, wheezing, facial angioedema, and fainting was reported (Patil et al., 1997; Faeste et al., 2009). It was interesting to notice that in certain ethnic groups, use of fenugreek seeds as food and herbal remedy, caused myopathy that was confirmed in ruminants (Egyed and Shlosberg, 1983). Fenugreek seeds are known to contain trypsin inhibitors cheymotrypsin inhibitors, and acetycholinesterase inhibitors (Duke, 2001; Beutler and Marderosian, 2002; Satheeskumar et al., 2010). Treatment with debitterized fenugreek powder $(10 \%$ in diet) failed to induce any toxicity and showed no effect either on the daily food intake or on growth (Muralidhara et al., 1999). Some studies also showed possible anti-fertility activity induced by fenugreek seeds (Kassem et al., 2006). However, no details are available in the scientific literature about the toxic potential of fenugreek seed extract upon chronic treatment.

Several crude drugs were previously reported to possess significant toxicity (Shah et al. 1989; Qureshi et al., 1990; Shah et al., 1998; Al-Ashban et al., 2005). Keeping in view the worldwide common use of fenugreek seeds in traditional medicine, and as food and spice, and the absence of reports on its adverse effects on chronic treatment, the present study was undertaken to investigate the toxicity of this popular natural drug after acute and chronic treatment in mice following World Health Organization (W.H.O.) protocol (WHO, 1967).

\section{MATERIALS AND METHODS}

\section{Plant extract}

The fenugreek seeds used in the current toxicity studies were collected from Riyadh region (Saudi Arabia) and identified by the Plant Taxonomy Unit of the College of Pharmacy, King Saud University, Riyadh, Saudi Arabia where the herbarium specimens (Voucher specimen \# 15853) were kept on record. The powdered seeds were extracted with $95 \%$ ethanol and later the 
solvent was evaporated at low pressure. The ethanol free extract was kept in refrigerator and used in the present investigations following ethical guidelines.

\section{Animal stock}

Swiss albino mice (home bred) aged 6 - 7 weeks, weighing about $22-26 \mathrm{~g}$, and fed on Purina Chow diet and water ad libitum were used in the present study. The animals were maintained under controlled temperature, humidity, and automated 12-h light/dark cycle (Shah et al., 1989).

\section{Acute toxicity}

A total of 20 mice were randomly allotted to one control and 3 treatment groups. The drug in each case was suspended in $0.1 \% \mathrm{CMC}$. The suspended extract was administered orally in three doses, namely $0.5,1.0$, and $3 \mathrm{~g} / \mathrm{kg}$ body weight. The toxic symptoms observed were autonomic responses, motor activity and CNS excitation, etc. The animals were observed for $24 \mathrm{~h}$ for all signs of toxicity and mortality (Shah et al., 1989; Al-Ashban et al., 2005). Acute treatment with $0.5 \mathrm{~g} / \mathrm{kg}$ was found to cause significant lowering in blood glucose levels in the treatment groups as compared to the control; hence, this dose was selected as the pharmacologically active dose.

\section{Chronic toxicity}

A total of 30 male and 30 female mice were randomly allotted to the control and the extracttreated groups separately ( 15 male and 15 female animals separately in each group). The fenugreek seed extract was given in drinking water (Shah $e t$ al., 1989). The dose selected was $100 \mathrm{mg} / \mathrm{kg} /$ day, which is $1 / 5$ of the pharmacologically active dose (Shah et al., 1989; Al-Ashban et al., 2005). The treatment was continued for a period of 3 months following W.H.O. protocol (W.H.O. 1967). The animals were observed for all external general symptoms of toxicity, body weight changes, and mortality daily up to the end of the experiment to analyze the impact of treatment. The average preand post-treatment body weights, vital organ weights, and viscera of the chronically treated animals were compared with the control group. The blood was analyzed for white blood cells (WBC), red blood cells (RBC), and haemoglobin using Contraves Digicell 3100H (Zurich). The blood biochemistry was performed by using Bohringer kits (Al-Ashban et al., 2005).

Furthermore, the chronically treated male animals were also analyzed for spermatogenic dysfunction using the sperm abnormality test, which is considered a reliable parameter for assessing germ cell mutagenicity and carcinogenicity (Bruce and Wyrobek, 1975; Wyrobek et al., 1983). The caudae epididymides and the vas deferens from the same animals were dissected out and transferred to a centrifuge tube containing $3 \mathrm{ml}$ Krebs Ringer bicarbonate buffer as described earlier (Al-Ashban et al., 2005). The sperm suspension was filtered through an $80 \mu \mathrm{m}$ silk mesh to remove tissue fragments and $0.5 \mathrm{ml}$ of $1 \%$ eosin $Y$ was added to each tube. The contents were thoroughly mixed and the slides were made by placing one drop of the solution on a slide and spread by three passes of another slide. Coded slides were examined for the following abnormalities of the sperm head: amorphous, flat head, microcephali, megacephali and swollen achrosome (Bruce and Wyrobek, 1975; Wyrobek et al., 1983).

\section{Histopathological procedures}

Tissue samples of liver, heart, testis, spleen, lungs, and kidney were preserved in $10 \%$ buffered formalin and processed for routine paraffin block preparation. Using an American Optical Rotary Microtome, sections of thickness about $5 \mu \mathrm{m}$ were cut and stained with haematoxylin and eosin. These were examined under the microscope for histopathological changes (Al-Ashban et al., 2005).

\section{Statistical analysis}

The different parameters studied were subjected 
to statistical analyses by the Chi-square test or student's $t$-test.

\section{RESULTS}

\section{Effect of acute treatment}

No alarming signs of toxicity except mild increase in respiration and excitation were seen in the mice treated with $3 \mathrm{~g} / \mathrm{kg}$ dose of fenugreek extract. No mortality was observed up to $3 \mathrm{~g} / \mathrm{kg}$ dose level during the acute toxicity test, indicating that the extract to be less toxic in the given dose levels (AlAshban et al., 2005).

\section{Effects of chronic treatment}

During chronic toxicity studies one male mice developed fore-limb inflammation at the end of the 30-days of treatment. The same male mice also developed alopecia at the end of 40 days. Two more male mice developed inflammation in the fore-limbs and hind limbs during 40-60 days of treatment. In the survival studies (Table 1). the lethality in the treatment groups was significantly higher $(P<0.05)$ as compared to the control group.

\section{Effects on body weight}

During the chronic treatment with fenugreek extract, the body weight gain was arrested in both male and female treatment groups (Table 2). as compared to control group. The slowness of growth was evident by body weights and was significant at $P<0.05$ and $P<0.01$ in male and female mice, respectively.

\section{Effect on water intake}

There was a significant increase $(P<0.05)$ in water intake of animals in both male and female control groups. However, increase in water intake in the treatment groups was not significant indicating toxic effect due to weight arrest caused by the treatment (Table 3).

\section{Effects on vital organ weights}

In the present study, prolonged treatment for 90 days had minimal effect on organ indices of animals. The observed increase in weight of kidneys in the treatment groups was statistically nonsignificant, however, in the male treatment group there was a significant decrease $(P<0.05)$ in the weight of testes as compared to the control (Table 4).

Table 1. Quantitative data on the mortality induced in mice on chronic treatment with ethanol extract of fenugreek seeds (T. foenum graecum)

\begin{tabular}{|c|c|c|c|c|c|c|c|c|c|c|c|c|}
\hline \multirow{3}{*}{$\begin{array}{l}\text { Treatment and dose } \\
100 \mathrm{mg} / \mathrm{kg} \text { ( } 3 \text { months })\end{array}$} & \multirow{2}{*}{\multicolumn{2}{|c|}{$\mathrm{N}$}} & \multicolumn{6}{|c|}{ Mortality } & \multicolumn{4}{|c|}{ Total dead animals Lethality (\%) } \\
\hline & & & \multicolumn{2}{|c|}{0 - 30 days } & \multicolumn{2}{|c|}{31 - 60 days } & \multicolumn{2}{|c|}{61 - 90 days } & \multirow{2}{*}{ M } & \multirow{2}{*}{$\mathrm{F}$} & \multirow{2}{*}{ M } & \multirow{2}{*}{$\mathrm{F}$} \\
\hline & M & $\mathrm{F}$ & $\mathrm{M}$ & $\mathrm{F}$ & $\mathrm{M}$ & $\mathrm{F}$ & $\mathrm{M}$ & $\mathrm{F}$ & & & & \\
\hline Control & 15 & 15 & 0 & 1 & 0 & 0 & 0 & 0 & 0 & 1 & 0 & 10 \\
\hline Fenugreek & 15 & 15 & 1 & 0 & 2 & 1 & 2 & 2 & 5 & 3 & $33^{*}$ & 20 \\
\hline
\end{tabular}

${ }^{*} P<0.05$ (Chi-square test). $\mathrm{M}=$ male mice, $\mathrm{F}=$ female mice

Table 2. Effect of chronic oral treatment with fenugreek seeds extract on body weight of mice ${ }^{a}$

\begin{tabular}{ccccc}
\hline Treatment and dose & Pre-treatment average body weight \pm S.E. & Post-treatment average body weight \pm S.E. \\
\cline { 2 - 4 } $100 \mathrm{mg} / \mathrm{kg}$ (3 months) & Male & Female & Male & Female \\
\hline Control (water) & $25.2 \pm 1.0$ & $24.2 \pm 1.2$ & $34.0 \pm 0.9^{* *}$ & $29.5 \pm 1.5^{*}$ \\
Fenugreek & $25.5 \pm 1.4$ & $25.1 \pm 1.8$ & $26.1 \pm 1.4^{* \mathrm{c}}$ & $25.2 \pm 1.5^{* \mathrm{c}}$ \\
\hline
\end{tabular}

Significant relative to pre-treatment values: ${ }^{*} P<0.05,{ }^{* *} P<0.01$ (Student's $t$-test). ${ }^{a}$ Fifteen male and fifteen female mice were used in each group. ${ }^{b}$ The average weight was calculated based on the number of surviving animals. ${ }^{c}$ Post-treatment average body weight of the treatment group was also compared with the control group. ${ }^{*} P<$ 0.001 (Student's $t$-test). 
Table 3. Effect of chronic oral treatment with fenugreek seed extract on the water intake of mice.

\begin{tabular}{ccccc}
\hline Treatment and dose & \multicolumn{2}{c}{$\begin{array}{c}\text { Pre-treatment average daily } \\
\text { water intake } \mathrm{ml} \pm \text { S.E. }\end{array}$} & \multicolumn{2}{c}{$\begin{array}{c}\text { Post-treatment daily average } \\
\text { water intake ml } \pm \text { S.E. }\end{array}$} \\
\cline { 2 - 5 } $100 \mathrm{mg} / \mathrm{kg}$ (3 months) & Male & Female & Male & Female \\
\hline Control (water) & $3.9 \pm 0.3$ & $3.8 \pm 0.2$ & $6.4 \pm 0.2^{*}$ & $6.1 \pm 0.4^{*}$ \\
Fenugreek & $4.1 \pm 0.4$ & $3.9 \pm 0.3$ & $5.2 \pm 0.3$ & $4.5 \pm 0.5$ \\
\hline
\end{tabular}

Significant relative to pre-treatment values: ${ }^{\star} P<0.05$, (Student's $t$-test)

Table 4. Effect of chronic oral treatment with fenugreek seeds extract on organ weights (per $100 \mathrm{~g}$ body weight) of mice

\begin{tabular}{|c|c|c|c|c|c|c|c|}
\hline Treatment and dose & \multicolumn{7}{|c|}{ Average organs weight (per $100 \mathrm{~g}$ body weight). } \\
\hline $100 \mathrm{mg} / \mathrm{kg}(3$ months $)$ & Heart & Lungs & Liver & Kidney & Spleen & Testis & Seminal vesicles \\
\hline Control & $0.45 \pm 0.02$ & $0.69 \pm 0.03$ & $5.25 \pm 0.25$ & $1.45 \pm 0.05$ & $0.53 \pm 0.07$ & $0.67 \pm 0.02$ & $0.86 \pm 0.14$ \\
\hline Fenugreek & $0.46 \pm 0.03$ & $0.80 \pm 0.23$ & $5.21 \pm 0.15$ & $1.68 \pm 0.09$ & $0.52 \pm 0.11$ & $0.55 \pm 0.05^{*}$ & $0.80 \pm 0.12$ \\
\hline
\end{tabular}

${ }^{*} P<0.05$ (Student's $t$-test). The tabular values represent the mean \pm S.E.M. of five randomly selected animals.

Table 5. Effect of chronic oral treatment with fenugreek seeds extract on the haematological parameters in mice

\begin{tabular}{cccc}
\hline Treatment and dose $(100 \mathrm{mg} / \mathrm{kg}, 3 \mathrm{months})$ & WBC $\times 10^{3}(\mathrm{~N} / \mathrm{ml})$ & $\mathrm{RBC} \times 10^{6}(\mathrm{~N} / \mathrm{ml})$ & Hemoglobin $(\%)$ \\
\hline Control & $5.26 \pm 0.65$ & $7.85 \pm 0.22$ & $11.94 \pm 0.45$ \\
Fenugreek $($ T. foenum graecum $)$ & $6.74 \pm 0.77$ & $7.69 \pm 0.24$ & $12.21 \pm 0.58$ \\
\hline
\end{tabular}

$P>0.05$ (Student's $t$-test). The tabular values represent the mean \pm S.E.M. of five randomly selected animals.

\section{Effects on hematological and biochemical parameters}

All the hematological parameters of both male and female mice remained within normal range and were comparable to the control groups after chronic treatment (Table 5).

On the other hand, the biochemical studies revealed a significant decrease $(P<0.05)$ in blood sugar levels and increase in ALT/GPT levels of animals in the treatment groups as compared to the control (Table 6).

Acute treatment with 0.5 and $1.0 \mathrm{~g} / \mathrm{kg}$ body weight in mice induced a significant $(P<0.001)$ fall in blood glucose levels after $6 \mathrm{~h}$ of treatment as compared to the control. The blood glucose lowering effect was also observed in animals after chronic treatment (Table 7).

\section{Effects on sperm morphology}

Treatment of male mice with fenugreek alcohol extract during the current study for 90 days
Table 6. Effect of chronic oral treatment with fenugreek seeds extract on the biochemical parameters in mice

\begin{tabular}{ccc}
\hline Parmaters & Control & Fenugreek \\
\hline Blood glucose $(\mathrm{mg} / \mathrm{dL})$ & $80.00 \pm 2.14$ & $49.50 \pm 3.91^{* *}$ \\
ALT/GPT $(\mathrm{U} / \mathrm{L})$ & $21.59 \pm 6.85$ & $27.50 \pm 4.98^{*}$ \\
AST/GOT $(\mathrm{U} / \mathrm{L})$ & $58.97 \pm 6.49$ & $56.77 \pm 7.61$ \\
CK-MB & $137.36 \pm 17.50134 .86 \pm 11.50$ \\
Creatinine $(\mu \mathrm{mol} / \mathrm{L})$ & $27.58 \pm 4.86$ & $29.27 \pm 3.66$ \\
Urea $(\mu \mathrm{mol} / \mathrm{L})$ & $8.10 \pm 1.99$ & $9.39 \pm 1.45$ \\
\hline
\end{tabular}

${ }^{*} P<0.05,{ }^{* *} P<0.01$, (Students $t$ '-test). Five animals were used in each group. Treatment groups were compared with the control.

clearly increased $(P<0.01)$ sperm morphological abnormalities as compared to the respective control group (Table 8). The indices screened for the morphological abnormalities, namely, swollen achrosomes, amorphous, microcephali, megacephali, rotated head and flat head showed significant increase in all these indices as compared to the control, indicating spermatotoxic properties of fenugreek seeds extract. 
Table 7. Effect of fenugreek seeds extract on blood glucose levels of mice in acute and chronic regimen

\begin{tabular}{ccccc}
\hline \multirow{2}{*}{ Group No. } & Treatment & \multicolumn{2}{c}{ Blood glucose level $(\mathrm{mg} / \mathrm{dl}$; Mean \pm SE) } \\
\cline { 3 - 4 } & & Day 0 & 6 hours & Day 90 \\
\hline 1 & Control & $76.9 \pm 1.71$ & $80.0 \pm 1.95$ & $80.0 \pm 2.14$ \\
2 & Fenugreek / Acute $0.5 \mathrm{~g} / \mathrm{kg}$ & $\mathrm{ND}$ & $55.9 \pm 4.40^{*}$ & ND \\
3 & Fenugreek / Acute $1 \mathrm{~g} / \mathrm{kg}$ & $\mathrm{ND}$ & $50.0 \pm 4.90^{*}$ & ND \\
4 & Fenugreek 100 $\mathrm{mg} / \mathrm{kg} /$ day (3M) & ND & ND & $49.5 \pm 3.91^{*}$ \\
\hline
\end{tabular}

$\mathrm{ND}=$ not done; $\mathrm{M}=$ months. 5 animals were used in each group. Treatment groups were compared to control at respective time points. Students' $t$-test. ${ }^{*} P<0.001$

Table 8. Effect of fenugreek seeds extract on the epididymal spermatozoa after chronic treatment in mice.

\begin{tabular}{|c|c|c|c|c|c|c|c|c|}
\hline \multirow[b]{2}{*}{ Treatment } & \multirow{2}{*}{$\begin{array}{c}\text { Total } \\
\text { sperms } \\
\text { screened }\end{array}$} & \multicolumn{6}{|c|}{ Percent sperm head abnormalities (Mean \pm S.E.) } & \multirow[b]{2}{*}{$\begin{array}{r}\text { - Abnormal } \\
\text { sperms }(\%)\end{array}$} \\
\hline & & $\begin{array}{c}\text { Swollen } \\
\text { achrosome }\end{array}$ & $\begin{array}{l}\text { Amor- } \\
\text { phous }\end{array}$ & $\begin{array}{l}\text { Micro- } \\
\text { cephali }\end{array}$ & $\begin{array}{c}\text { Mega-ceph- } \\
\text { ali }\end{array}$ & $\begin{array}{c}\text { Rotated } \\
\text { head }\end{array}$ & ead & \\
\hline Control & 4934 & $0.50 \pm 0.09$ & $0.40 \pm 0.09$ & $0.06 \pm 0.04$ & $0.06 \pm 0.04$ & $0.23 \pm 0.06$ & $0.04 \pm 0.02$ & $1.31 \pm 0.26$ \\
\hline Fenugreek & 5603 & $2.81 \pm 0.88^{* *}$ & $2.07 \pm 0.16^{* *}$ & $0.09 \pm 0.03^{*}$ & $0.49 \pm 0.09^{*}$ & $1.15 \pm 0.23^{* *}$ & $0.25 \pm 0.08^{*}$ & $3.98 \pm 1.70^{\star *}$ \\
\hline
\end{tabular}

${ }^{*} P<0.05,{ }^{* *} P<0.01$ (Students' $t$-test).

\section{DISCUSSION}

During the current acute toxicity test, no alarming signs of toxicity were seen except mild increase in respiration and excitation in the animals treated with the highest dose of $3 \mathrm{~g} / \mathrm{kg}$. None of the mice died up to $3 \mathrm{~g} / \mathrm{kg}$ dose level. Histopathological investigations proved the visceral condition and all vital organs to be normal and comparable to the control. Our results are in agreement with an earlier report documenting LD50 for fenugreek extract to be $5 \mathrm{~g} / \mathrm{kg}$ dose level (Muralidhara et al., 1999). There was a significant decrease in blood glucose level of mice during acute treatment. However, all hematological indices remained unchanged up to $3 \mathrm{~g} / \mathrm{kg}$ dose treatment as compared to the control.

During chronic toxicity studies, two male mice developed fore-limb inflammation and alopecia, while two other male mice developed inflammation in their fore-limbs as well as hind limbs in the treatment groups as compared to the control. These findings clearly indicated the prolonged fenugreek treatment to be toxic. However, in the female treatment group there were no toxicity symptoms. In the survival studies after fenugreek

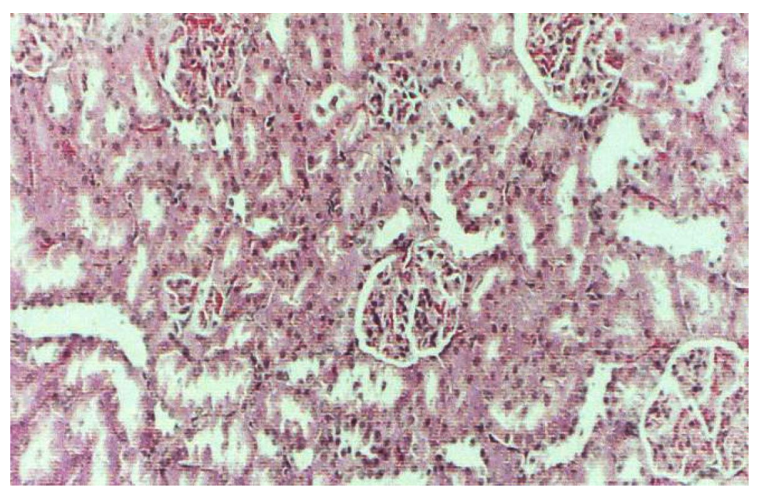

Fig. 1. Showing a control group mice kidney with normal appearance (Haemtoxylin-Eosin). Original magnification $\times 100$.

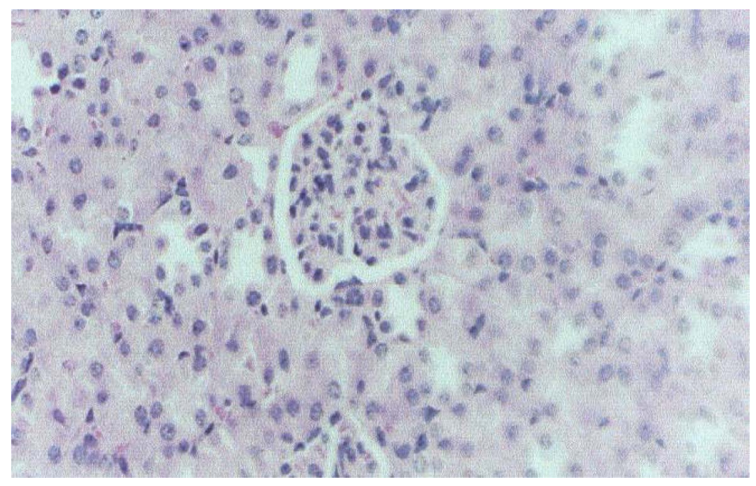

Fig. 2. Showing no change in kidney of an animal after chronic treatment with fenugreek seeds extract. (Haemtoxylin-Eosin). Original magnification $\times 100$. 
treatment for 90 days (Table 1). the lethality was significant in the last two months of treatment. In control group, one female mouse died during of 0-30 days of treatment. However, in the treatment groups, one male mouse died during 0-30 days of treatment; while two male and one female mouse died during 31-60 days of treatment. During 61-90 days of treatment, two more male and two female mice died. These results evidently verified the toxic potential of fenugreek seeds extract on prolonged treatment.

During the current chronic regimen of treatment with fenugreek extract, the slowness of growth was evident by body weights and was significant being $P<0.05$ and $P<0.01$ in male and female mice respectively as compared to the control. Similarly, the water intake was also affected. Our findings are not in full agreement with the observations of earlier studies (Bin-Hafeez et al., 2003; Shim et al., 2008). However, our results are supported by a report, where fenugreek treatment caused slowness in growth of animals (Muralidhara et al., 1999).

In our present study, the treatment protocol was extended to 90 days. The weight arrest observed in the treatment groups may be attributed to some fenugreek chemical constituents, such as protodioscin (Hibasami et al., 2003), galactomannan (Hannan et al., 2007; Srichamroen et al., 2009) which possess such properties and to the reduction of intestinal glucose up take caused by fenugreek treatment (Al-Habori et al., 2001, Srichamroen et al., 2009). In addition, fenugreek is known to posses hypocholesterolemic and hypotriglyceridmeic properties (Valette et al., 1984; Ribes et al., 1987; Al-Habori and Raman, 1998; Narender et al., 2006) which might also contribute to weight arrest.

Our findings are further supported by an earlier report where both oral and parenteral administration of fenugreek crude seed saponins for 21 days, lead to depress body weight in Hisextype chicks (Nakhla et al., 1991). It is worth mentioning that dietary fiber fraction of fenugreek seeds was found to inhibit carbohydrate digestion and absorption (Beutler and DerMarderosian, 2002; Vats et al., 2003; Hannan et al., 2007) resulting in growth arrest. Our results add support to all earlier reports where slowness of growth was recorded in animals treated with fenugreek.

In the present study, prolonged treatment of animals caused a significant reduction $(P<0.05)$ in weight of testes and some increase in the weight of kidneys that was statistically insignificant $(P>0.05)$. All other vital organs showed no significant changes as compared to the control. In contrast, in an earlier study, fenugreek treatment caused only reduction in weights of some vital organs and the authors ascribed no specific reason (Muralidhara et al., 1999). In another study fenugreek treatment induced no changes in the weights of vital organs (Bin-Hafeez et al., 2003). Similarly, fenugreek treatment for 30 days was also found to induce no significant decrease in the absolute weights of liver and kidneys (Kar and Tahiliani, 2003). However, treatment with fenugreek crude saponins, caused epithelial degeneration of renal tubules (Nakhla et al., 1991).

The mild increase observed in weight of the kidneys in current study, could possibly be attributed to the prolonged treatment protocol and to a probable accumulation of some of fenugreek extract constituents. Since the literature review, did not provide any such reference for comparison, the possibility of kidney weight increase by fenugreek treatment, could not be excluded (Ahsan et al., 1989; Rohini et al., 2009). To rule out the controversy, histopathological studies were conducted (Microphotograph 1, Microphotograph 2) which confirmed all the vital organs of the animals including kidneys, to be normal and comparable to the vital organs of mice in the control groups. Biochemical studies also revealed no significant differences in creatinine and urea levels of animals in the treatment groups as compared to the control. Thus confirming fenugreek treatment to be devoid of any toxic 
effects on kidneys of mice after chronic treatment.

After chronic treatment with fenugreek, all the hematological parameters remained within normal range and were comparable to the control groups. Our results are in agreement with the earlier findings (Muralidhara et al., 1999), which described hematological constants like WBC, RBC and hemoglobin to remain in normal range after prolonged treatment with de-bitterized fenugreek powder in rats, and proved that fenugreek chronic treatment was devoid of hematological toxicity.

In the present study, the biochemical parameters revealed a significant decrease in blood sugar levels of mice in the treatment groups as compared to the control. Our findings are in agreement with the earlier reports in the scientific literature; showing significant fall in blood glucose levels both in the normal as well as diabetic animals when treated with fenugreek seeds extract (Ghafghazi et al., 1977; Khosla et al., 1995; AbdelBarry et al., 1997; Ajabnoor and Tilmisany, 1998; Al-Habori and Raman, 1998). The hypoglycemic effect observed during the current toxicity studies on fenugreek seeds and the results of the earlier investigations add support to the traditional claim and medicinal use of fenugreek seeds by diabetic patient in different countries (Haddad et al., 2001; Beutler and Der Marderosian, 2002; Otoom et al., 2006).

Fenugreek seeds were reported to exhibit antidiabetic effect by changing of glucose and lipid metabolizing enzyme activities (Raju et al., 2001; Beutler and Der Marderosian, 2002; Hannan et al., 2007). However, the soluble dietary fiber fraction of fenugreek seeds was shown to exert antidiabetic effects mediated through inhibition of carbohydrate digestion and absorption, and enhancement of peripheral insulin action (Ali et al., 1995). Another report suggested that the hypoglycemic effect of fenugreek chemical constituents might be mediated through stimulation of insulin synthesis and/or secretion from the cells of Langerhans (Puri et al., 2002). The hypoglycemic effect of fenugreek treatment was slow and sustained, and without any risk of developing severe hypoglycemia (Ali et al., 1995; Ajabnoor and Tilmisany, 1998). Data from the literature further suggested that fenugreek treatment has been used to ameliorate 1-thyroxine-induced hyperglycemia in rats (Tahiliani and Kar, 2003).

The results of our current study further added support to the claimed hypoglycemic potential of fenugreek treatment (Beutler and DerMarderosian, 2002; Hannan et al., 2007; Srichamroen et al., 2009) which might be mediated through the inhibition of intestinal glucose uptake by galactomannan (Srichamroen et al., 2009); delaying the carbohydrate metabolism (Vats et al., 2003; Hannan et al., 2007). Furthermore, other contributing factor might the chemical constituents found in the defatted seed fractions (Ribes et al., 1987); alkaloid rich fraction (Shani et al., 1974; Puri et al., 2002), and compounds such as diosgenin (Pasich et al., 1983; Farnsworth and Marles, 1995), trigonelline (Mishkinsky et al., 1967), coumarin (Khurana et al., 1982), nicotinic acid (Duke, 2001), and 4-hydroxyisoleucine (Narender et al., 2006; Haeri et al., 2009) isolated from fenugreek seeds extract.

Fenugreek seeds were earlier reported to possess antioxidant activity (Dixit et al., 2005, 2008) and the hepatoprotective effect of fenugreek in chronic alcoholism, was attributed to polyphenols isolated from its seeds (Kaviarasan et al., 2008). However, during current study, there was a significant increase $(P<0.05)$ in ALT/GPT levels of animals in the treatment groups, which indicated an adverse effect on liver by prolonged use of fenugreek. Some of the fenugreek chemical constituents possessing anti-inflammatory (Vyas et al., 2008; Malviya et al., 2010), anticancer and antineoplastic effects (Sur et al., 2001; Raju et al., 2004; Amin et al., 2005; Shabbeer et al., 2009) may be held responsible for such activity. However, histopathological investigations revealed that the liver of animals in the treatment groups was normal and comparable to the control. 
During current study, fenugreek chronic treatment significantly decreased $(P<0.05)$ weight of testes in the male treatment group and significantly increased $(P<0.01)$ the sperm morphological abnormalities as compared to the control. In the present study, on average, the percentage of abnormal sperms increase, in the treatment group, was up to $3.98( \pm 1.70)$ percent; while in the control male mice percent abnormal sperm were $1.31( \pm 0.26) \%$. Noxious stimuli like chemicals and radiation are known to induce detrimental genotypic changes in the spermatogenic cells (Bruce and Wyrobek, 1974; Shah et al., 1989). The mouse sperm morphology assay, has been used to characterize mutagenic properties of a wide variety of chemicals (Bruce and Wyrobek, 1974; Wyrobek et al., 1983). Special Foodstuff formulated for people with diabetes, containing fenugreek extract with $40 \% \quad 4$ hydroxyisoleucine, was earlier found to possess no genotoxic properties (Muralidhara et al., 1999; Flamming et al., 2004; Dixit et al., 2008). However, the damage induced in the sperm morphology during the current study, reflected genetic damage in the male germ cells, either due to small deletions or point mutations (Bruce and Wyrobek, 1974; Wyrobek et al., 1983), or protein abnormality (Brinkworth et al., 1987; Flamming et al., 2004).

Several anticancer compounds were earlier reported to be germ cell toxicant/mutagen (Bruce and Wyrobek, 1974; Wyrobek et al., 1983). The spermatotoxic properties of fenugreek observed in the present study may be attributed to some of its chemical constituents possessing antineoplastic (Sur et al., 2001), anti-leukemic (Hibasami et al., 2003), antifertility (Kassem et al., 2006), and anticancer potential (Raju et al., 2004; Amin et al., 2005; Shabbeer et al., 2009).

Based on the results of present study, it is suggested that special caution must be taken when fenugreek seeds and/or their extracts are added to special foodstuff formulated for people with diabetes. Furthermore, the results of the current study provide basic information about the toxicity of fenugreek seeds that might be helpful in planning future pre-clinical experiments on this potent natural drug.

It is also worth mentioning that in our earlier experiments on herbal drugs with antidiabetic properties, for example: Artemisia abyssinica (Qureshi et al., 1990), Teucrium polium (Al-Ashban et al., 2005), and now Trigonella foenum-graecum, all were found to possess spermatotoxic activity and further studies are warranted on this issue.

\section{ACKNOWLEDGEMENTS}

The authors are thankful to Professor Dr. SultanulAbedin, Plant Texonomy Unit and Professor Dr. Mohammad A. Al-Yahya, Director, Research Centre, College of Pharmacy, King Saud University, Riyadh, Saudi Arabia for plant identification and specimen record.

\section{REFERENCES}

Abdel-Barry JA, Abdel-Hassan IA, Al-Hakiem MH. (1997) Hypoglycemic and antihyperglycemic effects of Trigonella foenum-graecum leaf in normal and alloxan induced diabetic rats. J. Ethnopharmacol. 58, 149-155.

Adamska M, Lutomski J. (1971) C-Glycoside flavones in the seeds of Trigonella foenum- graecum. Planta Med. 20, 224-229.

Ahsan SK, Tariq M, Ageel AM, Al-Yahya MA, Shah AH. (1989) Effect of Trigonella foenum-graecum and Ammi majus on the inhibition of Calcium oxalate urolethiasis in rats. J. Ethnopharmacol. 26, 249-253.

Ajabnoor MA, Tilmisany AK. (1998) Effect of Trigonella foenum-graecum on blood glucose levels in normal and alloxan diabetic mice. J. Ethnopharmacol. 22, 45-49.

Al-Ashban RM, Barrett DA, Shah AH. (2005) Effects of chronic treatment with ethanolic extract of Teucrium polium in mice". J. Herb Spices Med. Plants 11, 27-36.

Al-Habori M, Raman A. (1998) Antidiabetic and hypocholesterolaemic effects of Fenugreek. Phytother. Res. 12, 233-242.

Al-Habori M, Raman A, Lawrence MJ, Skett P. (2001) 
In vitro effect of fenugreek extracts on intestinal sodium-dependent glucose uptake and hepatic glycogen phosphorylase A. Int. J. Exp. Diabetes Res. 2, 91-99.

Ali L, Azad-Khan AK, Hassan Z, Mosihuzzaman M, Nahar N, Nasreen T, Nur-e-Alam M, Rokeya B. (1995). Characterization of the hypoglycemic effects of Trigonella foenum graecum seed. Planta Med. 61, 358-360.

Amin A, Alkaabi A, Al-Falasi S, Daoud SA. (2005) Chemopreventive activities of Trigonella foenum graecum (Fenugreek) against breast cancer. Cell Biol. Int. 29, 687-694.

Barnes J, Anderson LA, Phillipson JD. (2002) Herbal Medicines - A Guide for Healthcare Professionals. $2^{\text {nd }}$ ed., pp. 209-210, Pharmaceutical Press, London, UK.

Bin-Hafeez B, Haque R, Parvez S, Pandey S, Sayeed I, Raisuddin S. (2003) Immunomodulatory effects of fenugreek (Trigonella foenum-graecum L.) extract in mice. Inter. Immunopharmacol. 3, 257-265.

Brinkworth MH, Anderson D, Gangolli SD. (1987) Correlation of raised level of abnormal sperm morphology with electrophoretic sperm protein changes. Mut. Res. 2, 306-309.

Chopra RN, Nayar SL, Chopra IC. (1956) Glossary of Indian Medicinal Plants. pp. 248-249, Council of Scientific \& Industrial Research, New Delhi, India.

Dawidar AM, Saleh AA, El-Motei SL. (1973) Steroid sapogenin constituents of fenugreek seeds. Planta Med. 24, 367-370.

DerMarderosian A, Beutler JA. (2002) The Review of Natural Products. The Most Complete Source of Natural Product Information, pp. 253-254 Published by Facts and Comparisons, St. Louis, Missouri, USA.

Dixit PP, Devasagayam TP, Ghaskadbi S. (2008) Formulated antidiabetic preparation Syndrex has a strong antioxidant activity. Eur. J. Pharmacol. 581, 216-225.

Dixit P, Ghaskadbi S, Mohan H, Devasagayam TP. (2005) Antioxidant properties of germinated fenugreek seeds. Phytother. Res. 19, 977-983.

Duke JA. (2001) Handbook of Medicinal Herbs. P. 490, CRC Press LLC, Boca Raton, Florida, USA.

Dweck AC. (1997) African fragranced plants. Cosmet. Toiletries 112, 47-54.

Faeste CK, Namork E, Lindvik H. (2009) Allergenicity and antigenicity of fenugreek (Trigonella foenumgraecum) proteins in food. J. Aller. Clin. Immunol. 123, 187-194.

Flamming AM, Cifone MA, Erexson GL, Stankowski LF Jr. (2004) Genotoxicity testing of a fenugreek extract. Food Chem. Toxicol., 42, 1769-1775.

Ghafghazi T, Sheriat HS, Dastmalchi T, Barnett RC. (1977) Antagonism of cadmium and alloxaninduced hyperglycemia in rats by Trigonella foenum graecum. Pahlavi Med. J. 8,14-25.

Gruenwald J, Brendler T, Jaenicke C. (2000) PDR for Herbal Medicines. pp. 304-305, Medical Economics Company Inc. Montvale. New Jersey, USA.

Gupta RK, Jain DC, Thakur RS. (1986) Minor steroidal sapogenins from fenugreek seeds, Trigonella foenumgraecum. J. Nat. Prod. 49, 1153.

Haddad PS, Depôt M, Settaf A, Cherrah Y. (2001) Use of Antidiabetic Plants in Morocco and Québec. Diabetes Care 24, 608-609.

Haefelé C, Bonfils C, Sauvaire Y. (1997) Characterization of a dioxygenase from Trigonella foenum-graecum involved in 4-hydroxyisoleucine biosynthesis. Phytochemistry 44, 563-566.

Haeri MR, Izaddoost M, Ardekani MR, Nobar MR, White KN. (2009) The effect of fenugreek 4hydroxyisoleucine on liver function biomarkers and glucose in diabetic and fructose-fed rats. Phytother. Res. 23, 61-64.

Hannan JM, Ali L, Rokeya B, Khaleque J, Akhter M, Flatt PR, Abdel-Wahab YH. (2007). Soluble dietary fibre fraction of Trigonella foenum-graecum (fenugreek) seed improves glucose homeostasis in animal models of type 1 and type 2 diabetes by delaying carbohydrate digestion and absorption, and enhancing insulin action. Brit. J. Nutr. 97, 514-521.

Haouala R, Hawala S, El-Ayeb A, Khanfir R, Doughanmi N. (2008) Aqueous and organic extracts of Trigonella foenum-graecum L. inhibit the mycelia growth of fungi. J. Environ. Sci. China 20, 1453-1457. Hibasami H, Moteki H, Ishikawa K, Katsuzaki H, Imai K, Yoshioka K, Ishii Y, Komiya T. (2003) Protodioscin isolated from fenugreek (Trigonella foenum-graecum L.) induces cell death and morphological change indicative of apoptosis in leukemic cell line H-60, but not in gastric cancer cell line KATO III. Inter. J. Mol. Med.11, 23-26.

Hunt LM, Arar NH, Akana LL. (2000) Herbs, prayer, 
and insulin: use of medical and alternative treatments by a group of Mexican-American diabetic patients. J. Fam. Pract. 49, 216-223.

Hussein FTK. (1985) Medicinal Plants in Libya. P. 798, Arab Encyclopedia House, Beirut, Lebanon.

Karawya MS, Wassel GM, Baghdadi HH, Ammar NM. (1980) Mucilagenous contents of certain Egyptian plants. Planta Med. 38, 73-78.

Kassem A, Al-Aghbari A, Al-Habori M, Al-Mamary M. (2006) Evaluation of the potential antifertility effect of fenugreek seeds in male and female rabbits. Contraception 73, 301-306.

Kaviarasan S, Sundarapandiyan R, Anuradha CV. (2008) Protective action of fenugreek (Trigonella foenum graecum) seed polyphenols against alcoholinduced protein and lipid damage in rat liver. Cell Biol. Toxicol. 24, 391-400.

Kaviarasan S, Viswanathan P, Anuradha CV. (2007). Fenugreek seed (Trigonella foenum graecum) polyphenols inhibit ethanol-induced collagen and lipid accumulation in rat liver. Cell Biol. Toxicol. 24, 71-76.

Khater HF, Shalaby AA. (2008) Potential of biologically active plant oils to control masquito larvae (Culex pipiens, Diptera: Culicidae) from an Egyptian locality. Rev. Inst. Med. Trop. S. Paulo 50, 107-112.

Khosla P, Gupta DD, Nagpal RK. (1995) Effect of Trigonella foenum graecum (Fenugreek) on blood glucose in normal and diabetic rats. Indian J. Physiol. Pharmacol. 39, 173-174.

Khurana SK, Krishnamoorthy V, Parmar VS, Sanduja R, Chawla HL. (1982) 3,4,7-methyl-coumarin from Trigonella foenum-gracecum stems. Phytochemistry 21, 2145-2147.

Malviya KG, Babhulkar MW, Mali PY, Rangari VD. (2010) Evaluation of anti-inflammatory potential of Trigonella foenum-graecum (Fenugreek) seed extract by using carrageenan induced rat paw edema. Drug Invention Today 2, 109-111.

Marles RJ, Farnsworth NR. (1995) Antidiabetic plants and their active constituents. Phytomed. 2, 137-189.

Mishkinsky J, Joseph B, Sulman F. (1967) Hypoglycemic effect of trigonelline. Lancet 2, 1311-1312.

Mondal DK, Yousuf BM, Banu LA, Ferdousi R, Khalil M. and Shamim KM. (2004). Effect of fenugreek seeds on the fasting blood glucose level in the streptozotocin induced diabetic rats. Mymensingh
Med. J. 13, 161-164.

Murakami T, Kishi A, Matsuda H, Yoshikawa M. (2000) Medicinal foodstuffs. XVII. Fenugreek seed 3: Structures of new furostanol-type steroid saponins, trigoneosides $\mathrm{Xa}, \mathrm{Xb}, \mathrm{XIb}$, XIIa, XIlb, and XIIIa, from the seeds of Egyptian Trigonella foenum-graecum L. Chem. Pharm. Bull. (Tokyo), 48, 994-1000.

Muralidhara N, Narasimhamurthy K, Viswanatha S., Ramesh BS. (1999). Acute and subchronic toxicity assessment of debitterized fenugreek powder in the mouse and rat. Food. Chem. Toxicol. 37, 831-838.

Nakhla HB, Mohamed OS, Abu IM, Fatuh AL, Adam SE. (1991) The effect of Trigonella foenum graecum (fenugreek) crude saponins on Hisex-type chicks. Vet. Hum. Toxicol. 33, 561-564.

Narender T, Puri A, Shweta KT, Saxena R, Bhatia G, Chandra R. (2006) 4-hydroxyisoleucine an unusual amino acid as antidyslipidemic and antihyperglycemic agent. Bioorg. Med. Chem. Lett. (15-16), 293-296.

Otoom SA, Al-Saifi SA, Kerem ZK, Alkofahi A. (2006) The use of medicinal herbs by diabetic Jordanian patients. J. Herb Pharmacother. 6, 31-41.

Palaniswamy M, Pradeep BV, Sathya R, Angayarkanni J. (2008) In vitro anti-plasmodial activity of Trinonella foenum-graecum L. Evid. Based Complement. Alternat. Med., May 2. PMID: 18955334.

Pandian RS, Anuradha CV, Viswanathan P. (2002) Gastroprotective effect of fenugreek seeds (Trigonella foenum graecum) on experimental gastric ulcer in rats. J. Ethnopharmacol. 81, 393-397.

Pasich B, Terminska K, Beblot D. (1983) Diosgenin and yamogenin in domestic Semen foenugraeci. Herba Polonica 29, 203-209.

Patil SP, Niphadkar PV, Bapat MM. (1997) Allergy to fenugreek (Trigonella foenum graecum). Ann. Allergy Asthma Immunol. 78, 297-300.

Puri D, Prabhu KM, Murthy PS. (2002) Mechanism of action of a hypoglycemic principle isolated from fenugreek seeds. Ind. J. Physiol. Pharmacol. 46, 457462.

Qureshi S, Al-Yahya MA, Mossa JS, Tariq M, Ageel AM, Shah AH. (1990) Preliminary toxicity studies on ethanol extract of the aerial parts of Artemisia abyssinica and A. inculta. J. Ethnopharmacol. 28, 157162.

Raju J, Gupta D, Rao AR, Yadava PK, Baquer NZ. (2001). Trigonella foenum graecum (fenugreek) seed 
powder improves glucose homeostasis in alloxan diabetic rat tissues by reversing the altered glycolytic, gluconeogenic and lipogenic enzymes. Mol. Cell Biochem. 224, 45-51.

Raju J, Patlolla JM, Swamy MV, Rao CV. (2004). Diosgenin, a steroid saponin of Trigonella foenum graecum (Fenugreek), inhibits azoxymethane-induced aberrant crypt foci formation in F344 rats and induces apoptosis in HT-29 human colon cancer cells. Cancer Epidemiol. Biomarkers Prev. 13, 1392-1398.

Ribes G, Costa CD, Mariani LMM, Sauvaire Y, Baccou JC. (1987) Hypocholesterolemic and hypotriglyceridmeic effects of sub fractions of fenugreek seeds in alloxan diabetic dogs. Phytotherapeutic Res. 1, 8-43.

Rohini RM, Nayeem N, Das AK. (2009) Diuretic effect of Trigonella foenum-graecum seed extracts. Internet J. Alternat. Med. 6,ISSN 1540-2584.

Satheeshkumar N, Mukherjee PK, Bhadra S, Saha BP. (2010) Acetycholinesterase enzyme inhibitory potential of standardized extract of Trigonella foenum-graecum L. and its constituents. Phytomedicine 17, 292-295.

Sauvaire Y, Petit P, Broca C, Manteghetti M, Baissac Y, Fernandez-Alvarez J, Gross R, Roye M, Leconte A, Gomis R, Ribes G. (1998). 4-Hydroxyisoleucine: a novel amino acid potentiator of insulin secretion. Diabetes 47, 206-210.

Shlosberg A, Egyed MN. (1983) Examples of poisonous plants in Israel of importance to animals and man. Arch. Toxicol. Suppl. 6, 194-196.

Shabbeer S, Sobolewski M, Anchoori RK, Kachhan S, Davidson N, Carducci MA, Khan SR. (2009) Fenugreek: A naturally occurring edible spice as an anticancer agent. Cancer Biol. Ther. 8, 8 .

Shah AH, Al-Shareef AH, Qureshi S, Ageel AM. (1998) Toxicity studies on some common spices: Cinnamomum zylanicum and Piper longum. Plant Fds. Used in Human Nutr. 52, 231-241.

Shah AH, Qureshi S, Tariq M, Ageel AM. (1989) Toxicity studies on six plants used in Traditional Arab System of Medicine. Phytother. Res. 3, 25-29.

Shani J, Goldschmidt A, Joseph B, Ahronson Z, Sulma FG. (1974). Hypoglycemic effect of Trigonella foenum graecum and lupinus termis (Leguminosae) seeds and their major alkaloid in alloxan diabetic and normal rats. Arch. Inter. Pharmacody. Therapeut. 210, 27-36.

Shim SH, Lee EJ, Kim JS, Kang SS, Ha H, Lee HY, Kim
C, Lee JH, Son KH. (2008). Rat growth-hormone release stimulators from fenugreek seeds. Chem. Biodivers 9, 1753-1761.

Srichamroen A, Thomson AB, Field CJ, Basu TK. (2009) In vitro intestinal glucose uptake is inhibited by galactomannan from Canadian fenugreek seed (Trigonella foenum-graecum L) in genetically lean and obsess rats. Nutr. Res. 29, 49-54.

Sur P, Das M, Gomes A, Vedasiromoni JR, Sahu NP, Banerjee S, Sharma RM, Ganguly DK. (2001) Trigonella foenum graecum (fenugreek) seed extract as an antineoplastic agent. Phytother. Res. 15, 257-259.

Tahiliani P, Kar A. (2003) Mitigation of thyroxine induced hyperglycemia by two plant extracts. Phytotherapy Res. 17, 294-296.

Taylor WG, Zaman MS, Mir Z, Mir PS, Acharya SN, Mears GJ, Elder JL. (1997) Analysis of steroidal sapogenins from amber fenugreek (Trigonella foenumgraecum) by capillary gas chromatography and combined gas chromatography-mass spectrometry. J. Agric. Food Chem. 45, 753-759.

Thirunavukkarasu V, Anuradha CV, Viswanathan P. (2003) Protective effect of fenugreek (Trigonella foenum graecum) seeds in experimental ethanol toxicity. Phytother. Res. 17, 737-743.

Valette G, Sauvaire Y, Baccou JC, Ribes G. (1984) Hypocholesterolaemic effect of fenugreek seeds in dogs. Atherosclerosis 50, 105-111.

Vats V, Yadav SP, Grover JK. (2003) Effect of T. foenum-graecum on glycogen content of tissues and the key enzymes of carbohydrate metabolism. J. Ethnopharmacol. 85, 237-242.

Vyas S, Agrawal RP, Solanki P, Trivedi P. (2008) Analgesic and anti-inflammatory activities of Trigonella foenum-graecum (seed) extract. Acta Pol. Pharm. 65, 473-476.

W.H.O. Scientific Group. (1967). Principles for Preclinical Testing of Drugs Safety. Technical Report Series, 341, pp. 9-11. World Health Organization, Geneva, Switzerland.

Wyrobek AJ, Gordon LA, Burkhart JG, Francis MW, Kappa Jr. RW, Letz G, Malling HV, Topham JC, Whorton MD. (1983) An evaluation of the mouse sperm morphology test and other sperm tests in non-human mammals. Mut. Res. 115, 1-64.

Wyrobek AJ, Bruce WR. (1975) Chemical induction of sperm abnormalities in mice. Proc. Nat. Acad. Sci. 
USA, 72, 4425-4429.

Xu Y, Chen J, Mao H, Liu D. (1992) X-ray fluorescence spectrometric determination of phospholipids in semen Trigonella foenum-graecum. Fenxi-Huaxue 20, 219-222.

Yang WX, Huang HY, Wang YJ, Jia ZY, Li LL. (2005) Study on chemical constituents in total saponin from Trigonella foenum-graecum. Zhongguo Zhong Yao Za Zhi. 30, 1428-1430.

Yoshikawa M, Murakami T, Komatsu H, Murakami
N, Yamahara J, Matsuda H. (1997) Medicinal foodstuffs. IV. Fenugreek seed. (1): structures of trigoneosides $\mathrm{Ia}, \mathrm{Ib}$, IIa, IIlb, IIIa, and IIIb, new furostanol saponins from the seeds of Indian Trigonella foenum-graecum L. Chem. Pharm. Bull. (Tokyo) 45, 81-87.

Zhao HQ, Qu Y, Wang XY, Lu XY, Zhang XH, Hattori M. (2003) Determination of trigonelline by HPLC and study on its pharmacokinetics. Yaо Хue Хиe Ваo 38, 279-328. 